\title{
Molecular Species Composition of Phosphatidylcholine Isolated from Chum Salmon Meat Oil
}

\author{
Seung-Joo Lee, Wang-Hyun Ha, Hye-Jin Choi and Soon-Yeong Cho* \\ Department of Food Processing and Distribution, Gangneung-Wonju \\ National University, Kangnung 210-702, Korea
}

\begin{abstract}
Chum salmon (Oncorhynchus keta) meat oil contained high amounts of eicosapentaenoic acid (EPA) and docosahexaenoic acid (DHA) compared to oils extracted from other tissues of the fish. EPA and DHA occupied more than $25 \%$ of the total fatty acids in chum salmon meat oil. The main lipid classes in the meat oil were triacylglycerides and phospholipids. The major fatty acids of the molecular species composition of phosphatidylcholine isolated from the meat oil were DHA and EPA. DHA and EPA were the major molecular species in the phosphatidylcholine of chum salmon meat oil, representing $44 \%$ and $17 \%$, respectively.
\end{abstract}

Key words: Chum salmon meat, DHA, EPA, Phosphatidylcholine

\section{Introduction}

Seafoods from fish and marine invertebrates constitute globally important food sources. They are sources of proteins and lipids of high nutritional value in addition to being good sources of vitamins, minerals (Gonzalez et al., 2001), and other bioactive materials (Kim and Mendis. 2006). Fish are high in polyunsaturated fatty acids [n-3fatty acids, eicosapentaenoic acid (EPA; 20:5n-3) and docosahexaenoic acid (DHA; 22:6n-3)], which play an important role in human health and nutrition. These n-3 polyunsaturated fatty acids (PUFAs) are effective at lowering blood pressure, reducing hyperlipidemia and arrhythmias, and preventing arterial thrombosis and cardiovascular disease; they are anti-inflammatory, anticancer, and anti-obesity molecules (Li et al., 2003).

In addition, the high levels of EPA and DHA in marine lipids imply the presence of a strong antioxidant system in marine animal tissues. Antioxidants such as tocopherols are regarded as extremely important for preventing oxidation of marine lipids, but other factors have also been reported. Totani and Hara et al. found that phospholipids (PLs) were important factors that inhibited lipid oxidation (Hara et al., 1992; Segawa et al., 1995; Takeuchi et al., 1997). The importance of PLs has also been reported in a comparative study on the oxidation of lipids from

\footnotetext{
*Corresponding author: csykang@gwnu.ac.kr
}

different sardine and mackerel tissues (Ohshima et al., 1993). In addition, PLs are known as synergists in combination with phenolic antioxidants such as tocopherols (Ishikwa et al., 1984; King et al., 1992). Phosphatidylethanolamine (PE) and phosphatidylcholine (PC) are the most abundant phospholipids of eukaryotic cells, comprising $25 \%$ and $50 \%$, respectively, of cell phospholipid mass (White, 1973; Paltauf et al., 1992). We analyzed the molecular species composition of PC isolated from chum salmon meat oil.

\section{Materials and Methods}

\section{Materials}

Chum salmon (Oncorhynchus keta), with body lengths of $57.7 \pm 2.3 \mathrm{~cm}$ and body weights of 1,502 \pm $58.5 \mathrm{~g}$, were supplied by the Yangyang National fisheries Research \& Development Institute located in Yangyang-gun, Korea, in November 2007. After the removal of roe, samples of the whole body, meat, viscera, and other tissues were taken from each fish. Samples were frozen at $-70^{\circ} \mathrm{C}$ and then dried in a freeze-dryer.

\section{Oil extraction}

After putting $100 \mathrm{~g}$ of a vacuum freeze-dried sample in a $1,000 \mathrm{~mL}$ Erlenmeyer flask, we added $400 \mathrm{~mL}$ of $95 \%$ ethanol, which was four times greater $(\mathrm{w} / \mathrm{v})$ than the sample weight. Then, the sample was 
sonicated for $30 \mathrm{~min}$ (PowerSonic 520; Hwashin, Seoul, Korea) at $30^{\circ} \mathrm{C}$. After filtering with Whatman No. 2 filter paper, the extract was concentrated with a rotavator (R-200; Buchi, Flawil, Switzerland) and stored at $-40^{\circ} \mathrm{C}$.

\section{Proximate analysis}

Each chum salmon tissue sample was analyzed for its proximate composition (moisture content, crude protein, crude lipid, and crude ash) by the standard method of the Association of Official Analytical Chemists (AOAC, 1995). Carbohydrate content was calculated as the difference between $100 \%$ of the sample and the combined percentage of moisture, ash, crude protein, and total lipids.

\section{Fatty acid composition}

Fatty acid composition was analyzed by capillary gas chromatography (GC) after converting the fatty acyl groups in each lipid to their methyl esters by heating in a sealed tube at $90-100^{\circ} \mathrm{C}$ for $1 \mathrm{~h}$ with $7 \%$ boron trifluoride in methanol under nitrogen. The GC analytical conditions are shown in Table 1.

Table 1. Condition of gaschromatography analysis

\begin{tabular}{|c|c|}
\hline Oven & $\begin{array}{l}\text { Setpoint }-120^{\circ} \mathrm{C} \text {, Max. }-300^{\circ} \mathrm{C} \\
\text { Equilibration- } 3.00 \mathrm{~min}\end{array}$ \\
\hline Inlet & $\begin{array}{l}\text { Mode-split, Total flow- } 75.6 \mathrm{~mL} \\
\text { Pressure- } 9.52 \mathrm{psi} \text {, Split ratio- } 50: 1 \\
\text { Split flow- } 71.8 \mathrm{~mL} / \mathrm{MIN} \text {, Heater- } 250^{\circ} \mathrm{C} \\
\text { Gas saver- } 20.0 \mathrm{~mL} / \mathrm{min} \text {. Gas-He }\end{array}$ \\
\hline Column & HP-5 (5\% Phenyl methyl Siloxane), Temp.- $325^{\circ} \mathrm{C}$ \\
\hline Detector & $\begin{array}{l}\text { Heater- } 250^{\circ} \mathrm{C}, \mathrm{H}_{2} \text { flow- } 40 \mathrm{~mL} / \mathrm{min} \\
\text { Air flow }-450 \mathrm{~mL} / \mathrm{min} \\
\text { Makeup flow- } 45.0 \text {, Gas-He }\end{array}$ \\
\hline
\end{tabular}

\section{Isolation of phosphatidylcholine and phosphatidy- lethanolamine}

Phosphatidylcholine (PC) and phosphatidylethanolamine (PE) were further separated by silicic acid column chromatography using a chloroform/methanol solution as a developing solvent. Column chromatography separation was monitored by thin layer chromatography (TLC) using authentic standards, and was carried out on silica gel $60 \mathrm{GF}$ plates $(20 \times 20 \mathrm{~cm}, 0.05 \mathrm{~mm}$-thick layer; Merck, Darmstadt, Germany) that were developed with a chloroform/ methanol $/ 28 \%$ ammonia solution $(65: 35: 5, \mathrm{v} / \mathrm{v})$. Each of the PC and PE samples were minced and homogenized with chloroform/methanol $(2: 1, \mathrm{v} / \mathrm{v})$ according to the method of Bligh and Dyer (1959).

\section{Lipid class analyses}

TLC was conducted on $0.25 \mathrm{~mm}$ silica gel plates (Merck) that were developed with a chloroform/ methanol $/ 28 \%$ ammonia solution $(65: 35: 5, \mathrm{v} / \mathrm{v} / \mathrm{v})$. Lipid composition was determined quantitatively by a TLC-flame ionization detector (FID) on a Chromarod-S II using an Iatroscan TH-10 (Iatron, Tokyo, Japan). The sample solution was applied on each rod. The rods used for total lipid composition were developed $10 \mathrm{~cm}$ from the origin with chloroform/methanol/acetic acid $(8: 2: 0.1, \mathrm{v} / \mathrm{v} / \mathrm{v})$. Also, the rods used for phospholipid composition were developed at the origin with chloroform/methanol/water $(65: 25: 4, \mathrm{v} / \mathrm{v} / \mathrm{v})$. After the rods were developed, they were dried in a desiccator for a few minutes and scanned with the Iatroscan. The TLC-FID gas was hydrogen at a flow rate of $160 \mathrm{~mL} / \mathrm{min}$ and the scan speed was $30 \mathrm{~s}$.

\section{Molecular species composition of phosphatidyl- choline}

PC and PE analyses used TLC manufactured with $0.5 \mathrm{mg} / \mathrm{mL}$ methanol. Samples $(5 \mu \mathrm{L})$ were injected by HPLC into an AS3000 autosampler (Thermo Separation Production Products, San Jose, CA, USA), and a column (Gemini-5 $\mu$-c18-110A; Phenomenex, Torrance, CA, USA) was used. The column was kept at $20^{\circ} \mathrm{C}$ and had a flow solvent of $\mathrm{MeOH} / \mathrm{CAN} / \mathrm{TEA}$ $(60: 40: 0.1, \mathrm{v} / \mathrm{v})$ delivered at a flow rate of 0.5 $\mathrm{mL} / \mathrm{min}$ by a P4000 pump (Thermo Finnigan, Hemel Hempstead, UK), an L-7610 degasser (Hitachi, Tokyo, Japan), a CTO-10AS column oven (Shimadzu, Otsu, Japan), and a LCQ MS (Finnigan).

Table 2. Proximate compositions of each tissue parts of vacuum freeze dried chum salmon

\begin{tabular}{lccrr}
\hline Body tissue sections & Moisture (\%) & Crude protein (\%) & Crude lipid (\%) & Crude ash (\%) \\
\hline Whole body & $6.10 \pm .0 .04$ & $74.37 \pm 1.41$ & $8.89 \pm 0.07$ & $10.57 \pm 0.21$ \\
Meat & $4.34 \pm 0.04$ & $83.91 \pm 0.58$ & $5.67 \pm 0.09$ & $5.96 \pm 0.30$ \\
Viscera & $1.78 \pm 0.04$ & $81.95 \pm 1.88$ & $6.92 \pm 0.29$ & $7.70 \pm 0.06$ \\
The others & $3.45 \pm 0.03$ & $63.64 \pm 0.15$ & $12.58 \pm 0.07$ & $17.96 \pm 0.75$ \\
\hline
\end{tabular}

Values are mean $\pm \operatorname{SD}(n=9)$. 


\section{Results and Discussion}

\section{Proximate analysis}

The proximate compositions of each vacuum freeze-dried chum salmon tissue sample are shown in Table 2. The lipid content of the vacuum freeze-dried meat was approximately $5.67 \pm 0.09 \%$, and the protein content was approximately $83.91 \pm 0.58 \%$.

\section{Fatty acid composition}

The percentages by weight $(\mathrm{g} / 100 \mathrm{~g})$ for total fatty acids in the oils of each tissue type are shown in Table 3. Saturated fatty acids comprised $33.05 \%$, monoenoic fatty acids $38.14 \%$, and polyenoic fatty acids $28.8 \%$. The chum salmon fatty acid composition was similar to values report by Boyd et al. (1992), who examined the fatty acid composition of salmon meat oil. However, the values were different from the fatty acid composition of Coho salmon, for which saturated fatty acids comprised $24.43 \%$, monoenoic fatty acids $43.79 \%$, and polyenoic fatty acids $31.49 \%$ (Kim and Choi, 1993). The main fatty acids of chum salmon meat oil were palmitic acid (16:0), oleic acid (18:1n-9), EPA (20:5n-3), and DHA (22:6n-3). Oleic acid was the major monounsaturated fatty acid in chum salmon meat oil, representing $26.79 \%$. Chum salmon meat oil had the highest EPA content at $20.71 \%$. The EPA composition was similar to values reported by Moriya et al. (2007), who found that the EPA content of salmon roe and herring roe were $19.8 \%$ and $21.6 \%$, respectively.

\section{Lipid class analysis and molecular species com- position}

The lipid class composition of chum salmon meat oil is shown in Table 4. The triglyceride composition in the total lipids was $50.3 \pm 19.1 \%$. For comparison, Moriya et al. (2007) reported that the triglyceride content of salmon roe was $71.8 \%$. Also, as is shown in Table 4, the PE and PC content of chum salmon meat were $10.9 \pm 5.9 \%$ and $4.1 \pm 2.5 \%$, respectively.

The molecular species composition of PCs isolated from chum salmon meat were obtained by HPLC/ ESI-MS with a Gemini-5u-C18-110A (Table 5). The major components in the molecular species com-
Table 3. Fatty acid composition of the oils extracted from each tissue parts of chum salmon

\begin{tabular}{lcccc}
\hline & \multicolumn{4}{c}{ Composition $(\%)$} \\
Fatty acid & $\begin{array}{c}\text { Whole } \\
\text { body oil }\end{array}$ & Meat oil & $\begin{array}{c}\text { Viscera } \\
\text { oil }\end{array}$ & $\begin{array}{c}\text { The others } \\
\text { oil }\end{array}$ \\
\hline 4:0 & 1.86 & 0.97 & 2.11 & 1.89 \\
$12: 0$ & 0.43 & 0.07 & 0.12 & 0.23 \\
$14: 0$ & 5.38 & 3.43 & 3.73 & 7.22 \\
$15: 0$ & 0.57 & 0.39 & 0.43 & 0.66 \\
$16: 0$ & 19.30 & 16.64 & 22.46 & 19.53 \\
$17: 0$ & 0.32 & 0.40 & 0.50 & 0.55 \\
$18: 0$ & 5.07 & 3.83 & 6.52 & 4.57 \\
$20: 0$ & 0.12 & 0.31 & - & 0.24 \\
$21: 0$ & - & - & - & - \\
$22: 0$ & - & - & - & - \\
$23: 0$ & - & 0.11 & - & - \\
$24: 0$ & - & - & - & - \\
Saturated & 33.05 & 26.14 & 35.87 & 34.89 \\
$16: 1$ & 5.37 & 3.60 & 5.31 & 5.98 \\
$17: 1$ & - & - & - & - \\
$18: 1 T$ & 1.20 & 0.93 & 1.43 & 1.21 \\
$18: 1 C$ & 26.43 & 20.38 & 27.13 & 26.79 \\
$20: 1$ & 2.93 & 2.52 & 1.49 & 3.30 \\
$22: 1$ & 2.21 & 2.02 & 0.34 & 2.87 \\
$24: 1$ & - & 0.95 & - & 0.10 \\
Monoenoic & 38.14 & 30.39 & 35.69 & 40.26 \\
$18: 2 T$ & - & 0.17 & - & 0.13 \\
$18: 2 C$ & 1.95 & 2.93 & 1.34 & 1.74 \\
$18: 3 \omega 6$ & 6.29 & 6.77 & 1.67 & 8.08 \\
$18: 3 \omega 3$ & 1.73 & 1.77 & 1.01 & 1.85 \\
$20: 2$ & 0.57 & 0.83 & 0.48 & 0.86 \\
$20: 3 \omega 6$ & 0.09 & 0.44 & - & - \\
$20: 3 \omega 3$ & 0.09 & 0.41 & - & 0.22 \\
$20: 4$ & 0.81 & 1.00 & 1.77 & 0.58 \\
$22: 2$ & 0.00 & 0.09 & - & 0.15 \\
$20: 5 \omega 6$ & 5.53 & 8.35 & 9.68 & 4.01 \\
$22: 6 \omega 3$ & 11.74 & 20.71 & 12.48 & 7.22 \\
Polyenoic & 28.80 & 43.47 & 28.44 & 24.85 \\
\hline Valies & & & &
\end{tabular}

Values are mean $\pm \mathrm{SD}(\mathrm{n}=9)$.

position of PCs from chum salmon were DHA and EPA. However, in the saturated fatty acids, (SFA)/ PUFA, and monounsaturated fatty acids, (MUFA)/ PUFA, PC categories, 14:0, 16:0, 18:0, 16:1, and 18:1 species containing 22:6n-3 were more abundant than corresponding species containing 20:5n-3. These results are completely different from the sperm of Atlantic salmon and Chinook salmon in which 20:5n3 -containing molecular species were the major components (Bell et al., 1997).

Table 4. Lipid classes composition of oils extracted from chum salmon meat

\begin{tabular}{lcccc}
\hline & Whole body oil (\%) & Meat oil (\%) & Viscera oil (\%) & The others oil (\%) \\
\hline Triglyceride & $61.9 \pm 18.6$ & $50.3 \pm 19.1$ & $48.2 \pm 15.0$ & $79.1 \pm 10.7$ \\
Cholesterol & $2.2 \pm 1.0$ & $10.0 \pm 0.1$ & $4.1 \pm 0.9$ & $5.3 \pm 2.2$ \\
Phosphatidylethanolamine & $4.6 \pm 1.9$ & $10.9 \pm 5.9$ & $14.8 \pm 3.7$ & $6.2 \pm 6.5$ \\
Phosphatidylcholine & $5.9 \pm 0.6$ & $4.1 \pm 2.5$ & $20.2 \pm 13.9$ & $4.9 \pm 3.6$ \\
The other phospholipids & $24.5 \pm 18.2$ & $24.5 \pm 16.8$ & $12.0 \pm 7.8$ & $4.3 \pm 3.4$ \\
\hline
\end{tabular}

Values are mean $\pm \operatorname{SD}(\mathrm{n}=9)$. 
Table 5. Molecular species composition of phosphatidylcholine isolated from chum salmon meat obtained by HPLC/ESI-MS with Gemini-5u-C18-110A

\begin{tabular}{|c|c|c|c|}
\hline RT (Time) & {$[\mathrm{M}+\mathrm{Na}]+$} & $\begin{array}{l}\text { Molecular } \\
\text { species }\end{array}$ & $\begin{array}{c}\text { Peak area } \\
\%\end{array}$ \\
\hline 16.3 & 900.5 & $22: 6 / 22: 6$ & 3.08 \\
\hline 16.4 & 850.5 & $18: 3 / 22: 6$ & 0.35 \\
\hline \multirow[t]{2}{*}{17.5} & 774.5 & $14: 0 / 20: 5$ & 0.55 \\
\hline & 800.5 & $16: 1 / 20: 5$ & 0.36 \\
\hline 18.3 & 826.5 & $18: 2 / 20: 5$ & 0.28 \\
\hline 19.1 & 800.5 & $14: 0 / 22: 6$ & 1.53 \\
\hline 19.3 & 826.5 & $16: 1 / 22: 6$ & 1.30 \\
\hline 22.1 & 814.5 & $15: 0 / 22: 6$ & - \\
\hline 22.5 & 700.5 & $14: 0 / 14: 0$ & 0.26 \\
\hline 23.4 & 802.5 & $16: 0 / 20: 5$ & 14.08 \\
\hline 24.1 & 828.5 & $18: 1 / 20: 5$ & - \\
\hline 25.5 & 828.5 & $16: 0 / 22: 6$ & 26.54 \\
\hline 26.3 & 854.6 & $18: 1 / 22: 6$ & - \\
\hline \multirow[t]{2}{*}{28.8} & 804.5 & $16: 0 / 20: 4$ & 1.42 \\
\hline & 830.5 & $16: 0 / 22: 5$ & 1.79 \\
\hline 30.1 & 842.5 & $17: 0 / 22: 6$ & 0.33 \\
\hline 30.6 & 754.5 & $16: 0 / 16: 1$ & 3.17 \\
\hline 31.7 & 814.6 & $15: 0 / 22: 6$ & 10.73 \\
\hline \multirow{2}{*}{31.8} & 830.6 & $18: 0 / 20: 5$ & 1.64 \\
\hline & 780.6 & $16: 0 / 18: 2$ & 0.84 \\
\hline 34.6 & 882.5 & $20: 1 / 22: 6$ & 0.66 \\
\hline 35.1 & 856.6 & $18: 0 / 22: 6$ & 2.63 \\
\hline 35.8 & 768.6 & 15:0/18:1 & 0.57 \\
\hline 39.8 & 858.6 & $18: 0 / 22: 5$ & - \\
\hline 42.3 & 782.6 & 16:0/18:1 & 23.69 \\
\hline 44.7 & 808.5 & 18:0/18:2 & - \\
\hline 59.4 & 810.6 & 18:0/18:1 & 4.19 \\
\hline 76.1 & 770.5 & $17: 0 / 16: 0$ & - \\
\hline \multicolumn{3}{|c|}{ Total (Each otherfatty acids/22:6) } & 44.07 \\
\hline \multicolumn{3}{|c|}{ Total (Each other fatty acids/20:5) } & 16.91 \\
\hline
\end{tabular}

\section{Acknowledgments}

This work was supported by the National Research Foundation of Korea(NRF) grant funded by the Korea government(MEST)(No. 2009-0083-638).

\section{References}

AOAC. 1995. Offical Methods of Analysis 16th ed. Association of official analytical chemists, Washington D.C., U.S.A., 69-74.

Bell MV, Disk JR and Buda CS. 1997. Molecular speciation of fish sperm phospholipids: Large amounts of dipolyunsaturated phosphatidylserine. Lipids 32.

Bligh EG and Dyer WJ. 1995. A rapid method of total lipid extraction and purification. J Biochem Physiol 37, 911917

Gonzalez M, Caride B, Lamas MA, Taboada C. 2001. Nutritional value of the marine invertebrates anemonia viridis and haliothis tuberculata and effects on serum cholesterol concentration in rats. J Nutr Biochem 12, 512-517
Hara S, Okada N, Hibino H and Totani Y. 1992. Antioxidative behavior of phospholipids for polyunsaturated fatty acids of fish oil. J Jpn Oil Chem Soc 41, 130-135.

Ishikwa Y, Sugiyama K and Nakabayashi K. 1984. Stabilization of tocopherol by three components synergism involving tocopherol, phospholipid and amino compound. J Am Oil Chem Soc 61, 950-954.

Kim KS and Choi YJ. 1993. Food components of coho salmon and rainbowtrout. Korean J Food Nutri 6, 73-80.

Kim SK, Mendis E. 2006. Bioactive compounds from marine processing byproducts-A review. Food Res Int 39, 383-393.

King MF, Boyd LC and Sheldon BW. 1992. Effects of phospholipids on lipid oxidation of a salmon oil model system. J Am Oil Chem Soc 69, 237-242.

Li D, Bode O, Drummond H and Sinclair AJ. 2003. Omega-3 (n-3) fatty acids. In lipids for functinal foods and nutraceuticals; Gunstone, F. D., Ed.; The Oily Press: Bridgwater, England 20, 225-262.

Moriya H, Kuniminato T, Hosokawa M, Fukunaga K, Nishiyama T and Miyashita K. 2007. Oxidative stability of salmon and herring roe lipids and their dietary on plasma cholesterol levels of rats. Fisheries Science 73, 668-674

Ohshima T, Fujita Y and Koizumi C. 1993. Oxidative stability of sardine and mackerel lipids with reference to synergism between phospholipids and a-tocopherol. J Am Oil Chem Soc 70, 269-276.

Paltauf F, Kohlwein SD and Henry SA. 1992. Regulation and compartimentalization of lipid synthesis in yeast, The molecular and cellular biology of the yeast saccharomyces: Gene Expression, Cold Spring Harbor Laboratory Press, Plainview, NY., 415-500.

Segawa T, Kamata M, Hara S and Totani Y. 1995. Antioxidative behavior of phospholipids for polyunsaturated fatty acids of fishoil. III: Synergistic mechanism of nitrogen including phospholipidsfor tocopherol. J Jpn Oil Chem Soc 44. 36-42.

Takeuchi M, Hara S, Totani Y, Hibino H and Tanaka Y. 1997. Antioxidative behavior of polyunsaturated phospholipids. I: Oxidative stability of marine oil containing polyunsaturated phospholipids. J Jpn Oil Chem Soc 46, 175-181.

White DA. 1973. The phospholipid composition of mammalian tissues In: Ansell GB, Hawthorne JN and Dawson RMC. Editors, form and function of phospholipids, Elsevier Scientific, Amsterdam, 441-482.

(Received 16 August 2010; Revised 18 August 2010; Accepted 20 September 2010) 